Kathryn L. Allen, UNIVERSITY OF WISCONSIN OSHKOSH, allenk@uwosh.edu

Katherine Brodeur, BOWLING GREEN STATE UNIVERSITY, brodeuk@bgsu.edu

Madeleine Heins Israelson, COLLEGE OF SAINT BENEDICT/ST. JOHN'S UNIVERSITY,

misraelson@csbsju.edu

Keitha-Gail Martin-Kerr, UNIVERSITY OF MINNESOTA, kmartink@umn.edu

Lisa Ortmann, UNIVERSITY OF NORTHDAKOTA, lisa.ortmann@und.edu

Debra S. Peterson, UNIVERSITY OF MINNESOTA, peter328@umn.edu

\title{
Developing Reflective Practice in Teacher Candidates Through Program Coherence
}

\section{ABSTRACT}

In this study, we explored the role of reflection at three stages of preparation across a teacher education program. Reflection has long been considered an essential aspect of professional practice for teaching; however, reflection is often vague and undefined. Through an examination of the opportunities we provided for our students to reflect, and systematic analysis of the levels of reflection our students engaged in, we found that the development of reflective practices could be understood and aligned across a professional preparation program. Furthermore, we considered our own pedagogical practices related to modality, prompting, scaffolding, assignment structure, and feedback in our analysis of a variety of student reflection artifacts, in order to understand the potential impact of our own pedagogical decisions across the program. Findings suggest that the program provided modeling and structures for reflection early on, encouraged the inclusion of multiple perspectives in relation to professional practice, and supported a synthesis of student learning of theory and practice as preservice teachers approached program completion. This article offers reflection as a tool for exploring issues of professional growth across a continuum of development.

\section{KEYWORDS}

reflection, teacher education, pedagogy

\section{INTRODUCTION}

A common and essential goal many educators espouse for their students is to develop meaningful, lifelong reflective practices that will support their continuous learning and growth as professionals (Parkinson, 2008). Reflection can be a "lens into the world of practice" (Loughran, 2002, p. 37) that can lead to new understandings and revisions in one's own thinking (Panos, 2015). This is an essential skill in any profession as one continues to learn throughout one's career. For example, in medical education Jarvis-Selinger, Pratt, and Regehr (2012) posited that preparing people for a profession involves more than just developing competencies. It includes socializing them into the roles, identities, and dispositions necessary in that profession. Reflective practice is one professional disposition that students can learn through interactions with colleagues in their preparation programs, but the challenge is how to develop this disposition in such a way that the practice continues beyond the 
training program (Nelson \& Sadler, 2013). Additionally, researchers have called attention to the lack of studies that have included evidence of educators engaging in reflection on their own teaching (Russell \& Martin, 2007).

As teacher educators, we have come to value the act of reflecting for continually refining and improving our own teaching, as well as for enhancing the work our students do as they learn to teach elementary school children. Our varied experiences as educators, supported by theory that establishes the power of reflection (e.g., Hayden \& Chiu, 2013), motivated us to be intentional in how we incorporated the development of reflective practices into our instruction. It was this belief in the value of reflective practice that prompted us to more rigorously study its development in our students.

As we began our review, we realized that we continued to wrestle with finding effective ways to teach reflection that would meet our goals of developing students' capacities as reflective practitioners. We did not have a consistent definition of reflection or common expectation of what reflection would look like in practice. Clarà (2014) suggests that ambiguities in definitions of reflection demand clarification, particularly when being used as a transformative pedagogical tool. Through deeper examination of our students' reflections, as well as the conditions we created to evoke them, we learned more about how reflective practice develops in students entering a new profession, and about ways in which we, as educators, can provide opportunities to support this development. The following research questions guided our study:

\section{What opportunities to reflect are we providing for students across the teacher education program?}

2. How do the opportunities we construct support students as they grow in their ability to engage in advanced levels of reflection?

\section{Background}

Conventional understandings of reflection originating from the work of Dewey $(1933 ; 1938)$ and Schön $(1983 ; 1987)$ emphasize reflection as a critical cognitive process in making sense of experience. Schön's theory of reflective practice is widely used in professional education programs such as architecture, accounting, nursing, and teaching. Schön (1987) suggests that professional "reflection on-action," or "[ $\mathrm{t}]$ hinking back on what we have done in order to discover how our knowing-in-action may have contributed to an unexpected outcome" (p. 26) may lead to growth in professional practice. Hiebert et al. (1996) interpreted reflective thinking as a "systematic" practice that should cause professionals to "wonder why things are, to inquire, to search for solutions, and to resolve incongruities" (p. 12). In taking this inquiry stance to learning, teachers are better able to critically enact the learning gained from reflection on content and pedagogy (Shulman, 1987).

More recently, reflective practice has offered a space for teachers to bring together observations, classroom experiences, and academic knowledge to form plans with specific steps and purposes for future action (Bransford, Darling-Hammond, \& LePage, 2005). Programs of teacher education have worked to support students in developing the ability to "let go of previously held beliefs and tolerate the ambiguity of having to rethink one's perspective" (Bransford et al., 2005, p. 51). Reflective practice has been shown to lead to purposeful action and to support students' capacity for critical self-examination, learning, and change (Snow, Griffin, \& Burns, 2005). 


\section{Arriving at a working definition of reflection}

We defined reflection as an ongoing, recursive process that practitioners engage in as they deeply analyze the connections between aspects of professional practice. For teachers, this includes their instructional planning, teaching, and assessment of student learning. We understand products of reflection, such as written notes, learning community conversations, and individual commentaries to be momentary windows into practitioners' ongoing reflective thinking.

Reflective practice for teachers, grounded in professional knowledge and knowledge of students (Shulman, 1987), provides tools through which preservice teachers learn how to adapt instruction to their student needs, contexts, or situations. Reflection may include justifying planning decisions, analyzing teaching, and using data to inform instruction as well as the examination of the teacher's experiences (Snow et al., 2005). Preservice teachers must be able to reflect on the theories and analytical frames and assumptions through which they make sense of their practice (Bransford, Derry, Berliner, Hammerness, \& Beckett, 2005) and have access to tools through which to address tensions among differing perspectives and their own personal beliefs (Freese, 2006). Our goal in this study was to explore how we constructed opportunities for reflection in our teacher education program to increase teacher candidates' ability to engage in reflective practice.

This definition of reflection, with a particular focus on instructional decisions, led us to modify and utilize Risko, Vukelich, and Roskos's (2009) reflection rubric (Appendix A). Risko et al. (2009) established that reflective practices, though recognized as vital, are inconsistently taught. This finding, as well as the reflection rubric, resonated with us and our working understanding of reflection and guided our inquiry into the quality of reflections as students progressed through three stages of coursework. Modifications to the rubric were made based on our definition of reflection. For example, on the original rubric the three levels of performance were titled "Below," "At Target," and "Above." We modified the levels of performance to be "Emerging," "Developing," and "Advanced," which are terms consistent with developmental models of education.

\section{METHODS}

As a team of six teacher educators at a large, public university in a Midwestern city in the United States, we initially collaborated to discuss alignment of the three stages of literacy courses in our teacher preparation program. Through our adaptation of and work with Risko et al.'s (2009) rubric, our discussions occasionally diverged to what the rubric did not address: the teacher candidates' development of professionalism or the growth in their ability to recognize and reflect on critical issues like personal biases related to social class, ethnicity, or gender. To elevate our work beyond our own individual reflections, we engaged in a systematic study of our teaching practices with interest in our students' developing capacity for reflection, and the implications on our professional program.

\section{Context}

Participants in this study were 78 preservice teachers at a large urban university in the Midwestern United States. All the participants were preparing to be elementary general education teachers. The students progressed through three required literacy courses in a sequential manner as they moved through the licensure program. The courses and their content will be briefly described below (see Table 1.) 
Table 1. Literacy coursework and field experiences in out teacher preparation program

\begin{tabular}{|l|l|l|l|l|}
\hline PROGRAM STAGE & LITERACY COURSE & PROGRAM LEVEL & FIELD EXPERIENCE & DURATION \\
\hline Beginning & $\begin{array}{l}\text { Foundations of } \\
\text { Literacy }\end{array}$ & undergraduate & Tutoring 1-1 & $\begin{array}{l}\text { 2 days a week for } \\
\text { one semester }\end{array}$ \\
\hline Middle & Methods & graduate & Small group & $\begin{array}{l}\text { Four 2 week blocks } \\
\text { for one semester }\end{array}$ \\
\hline End & Capstone & graduate & Full class & $\begin{array}{l}\text { Full time for one } \\
\text { semester }\end{array}$ \\
\hline
\end{tabular}

The first stage, Foundations, presented research and theory related to children's literacy development. Preservice teachers also participated in an accompanying practicum experience conducted in local elementary schools. Throughout the semester, preservice teachers worked two mornings a week to administer literacy assessments to two elementary students and used the results to plan weekly tutoring sessions.

The second stage, Methods, included two literacy courses designed to advance understanding and practical application of curricular and methodological issues in teaching reading and language arts. Concurrently, preservice teachers participated in field work which operated on a block schedule, alternating between two weeks on campus and two weeks in field placement classrooms. The preservice teachers remained in these same placements for their student teaching the following semester.

The third stage, Capstone, occurred during the semester when the preservice teachers were engaged in full time student teaching in elementary classrooms. At this stage, the preservice teachers completed a performance assessment including lesson plans, video clips of instruction, and written reflections.

\section{Data collection and analysis}

Data sources used to address our first research question included the collection and analysis of instructional materials such as PowerPoint and lecture notes, course handouts and assignments, syllabi, and course calendars. Information from these sources was compiled to identify the types of reflection activities provided in our courses, the prompts we used, and the frequency with which we engaged preservice teachers in the reflective process across all levels of the program. Using a data matrix (Miles \& Huberman, 1994), we organized the data in order to compare and contrast the opportunities we provided and the opportunities or constraints on student development.

To respond to our second research question, we analyzed preservice teachers' written reflections, first scoring each artifact of reflection against the revised reflection rubric (Risko et al., 2009), followed by noting patterns and developing corresponding codes. In order to provide consistency across research cases, all artifacts of reflection were scored and coded individually by two researchers. Researchers then met to compare scores and resolve differences. A random sample of the artifacts was again scored and coded by a third researcher. 
Once the reflections were scored, we looked at the results in a variety of ways. We examined the total score for each preservice teacher to determine whether there was evidence of a developmental progression across the levels of reflection. Initial patterns led us to a deeper analysis of one of the components of the reflection rubric, the Instructional Decisions category. Instructors from each stage of coursework agreed that this was the element most consistently emphasized across our teacher education program. Analysis of rubric scores on Instructional Decisions provided frequency counts per stage for each developmental level of reflective practice.

\section{FINDINGS}

\section{Research question 1}

In each of the three programmatic stages, instructors carefully and deliberately designed opportunities to provide structured support for developing practitioners. Across courses, we found that while we collected similar artifacts of reflective thinking, the purposes and expectations for these opportunities varied as students progressed. The learning objectives, structures, and embedded State Board of Teaching standards in each course shaped the purposes and expectations of each opportunity to reflect.

\section{Reflection opportunities specific to the Foundations stage}

In the Foundations class, preservice teachers were invited to talk about their tutoring experiences within their peer groups without the explicit information that this was a type of reflecting. The preservice teachers were asked to use data from assessments and lesson plans to reflect forward about what they anticipated would happen in the next teaching cycle. These reflections included lesson plans, peer-group conversations, and written reflections. Each of these opportunities was repeated frequently to promote reflective practice as a habit for preservice teachers early in their professional learning.

The lesson plan format used in the Foundations class was fortified with prompts requiring reflection on assessment data, in part to prepare preservice teachers for the more rigorous expectations of lesson-planning in the Methods class and for the Capstone portfolio. The focus on data provided an opportunity for preservice teachers to make concrete connections between assessment and instruction while tutoring their elementary school students.

In Foundations, peer-group discussions were the most immediate opportunity to reflect after teaching. Instruction was provided in approaches to peer coaching, an approach that pairs students together to engage in reflective dialogue about teaching, in order to promote reflection as a way to solve problems of practice with the support of peers. Despite given prompts, these conversations often veered in response to the events of individuals' tutoring experiences. Instructors supported this open-ended practice as we recognized the value of just-in-time support as part of a developing professional practice (Hattie \& Timperley, 2007); however, the depth and content of these reflections varied due to this approach.

Written reflections on tutoring sessions occurred within a week of teaching and were composed and submitted online individually. Focused on both the descriptive (What happened?) and the analytical (What are some possible reasons why things went the way that they did?), preservice teachers analyzed students' responses to their instruction in order to plan fitting instruction for the next session. 
Overall, the opportunities to reflect in Foundations were both the most frequent and the most carefully structured. Preservice teachers observed modeling and participated in guided practice for the types of reflective language expected for lesson plan and peer-group opportunities. In addition to developing peers' capacity to support each other, instructors interacted with peer groups and provided feedback on other written reflection opportunities.

\section{Opportunities to reflect specific to the Methods stage}

During the Methods course, preservice teachers were in the first semester of a year-long field placement. As they co-taught with cooperating mentor teachers, they gradually assumed responsibility for instruction through small and whole group lessons. Reflection-based assignments were less frequent than in the Foundations class but considerably more comprehensive in nature. Written reflection was the preferred modality and the expectations for writing increased in length, depth, and professionalism. Opportunities to reflect in the Methods course included lesson plans, peer group conversations, and written reflections. Each of these opportunities was repeated four times during the semester to allow preservice teachers to ground their reflective practices in their field work.

Methods class reflections were generally two to three typed pages in length and written within a week of teaching the lesson and conferring with a university supervisor. Reflection was prompted to focus on the success of different learners and subgroups within the class. This promoted a mindset geared toward acknowledging student differences and the need for differentiation. This reflection opportunity also fostered reflection for continual learning and professional growth.

Methods reflection continued to provide a space for the preservice teachers to express their feelings about their current field placements as well as their place within the larger educational landscape. They were prompted to explore their developing sense of teacher identity and evaluate aspects of the state of the education system. They were encouraged to reflect on what they would change if they could. These opportunities were also guided by peer feedback and not evaluated by instructors.

Overall, opportunities to reflect in Methods required a depth of personal and professional selfexamination suitable to this medial stage in the preservice teachers' preparation. With sufficient field experience to ground their developing opinions and identities as professionals, peers became a greater source of feedback as preservice teachers gained experience, providing a more authentic context of collegial reflection.

\section{Opportunities to reflect specific to Capstone}

The Capstone course was unique in its position as the culminating course of the licensure program. The primary goals were to link theory and practice, and to challenge the preservice teachers to integrate what they have learned in coursework with their experiences in the classroom. Detailed lesson plan assignments synthesized theory with teaching practice. Specifically, candidates were required to integrate research-based instructional models, learning objectives, plans for differentiation for students' diverse linguistic and academic needs, and learning theories into their lessons. Plans for daily instruction during student teaching were discussed and reviewed by peers, co-teachers, instructors, and supervisors. The feedback was intended to deepen the preservice teachers' reflection on instruction and student learning. 
Because of their full-time placements in the field, preservice teachers in the Capstone course met once a month in seminars, weekly in small groups of three or four with their university supervisors, and completed weekly assignments online. At four points during the semester, preservice teachers engaged in face-to-face peer group discussions, to reflect on their elementary students' progress. Feedback in these forums was given by peers and university supervisors, and focused on offering divergent perspectives.

Capstone students completed formal written reflections five times within the semester. The prompts for these assignments maintained a focus on the relationship between student learning and instructional decisions; however, greater detail was expected than in Methods as the preservice teachers were asked to name instructional strategies and make connections to research and theory. In this more formal reflection assignment the preservice teachers were asked to take up academic discourse to describe their observations of their students' responses to instruction.

\section{Summary}

Across these three stages of literacy teacher preparation, "reflection" was constructed through four primary types of course assignments: written reflections, lesson planning, peer group conversations, and video reflection, and held a variety of meanings for the preservice teachers enrolled in this elementary education program. Expectations for what reflection could or should look like changed as students progressed through the courses, ultimately addressing facets of personal and professional dispositions over the three semesters. Though they had many opportunities to practice reflection through multiple modalities in their initial Foundations class, the preservice teachers were expected to compose longer texts with greater amounts of introspection and/or academic discourse as they progressed through the program. The preservice teachers were also expected to assume more responsibility as professional colleagues throughout this program as they were increasingly asked to provide feedback for peers as their knowledge base and professional experiences grew.

\section{Research question 2}

We examined student work from three levels of teacher preparation, using the revised reflection rubric to guide our process, focusing intentionally on the characteristic of instructional decision making. We chose this because it most closely related to the type of reflection we highlighted within our coursework, asking for evidence of "adaptations that are specific instructional techniques or strategies and are based on students' performance, knowledge of research, theory, and course content” (see reflection rubric, Appendix A). The preservice teachers' performance at points in time along this characteristic provides evidence of their growing ability to reflect on practice in ways that develop adaptability and independence.

Written reflections from each level of teacher preparation were analyzed according to the descriptors of instructional decision making at emerging, developing, and advanced levels. We considered preservice teachers' reflections that listed global, descriptive adaptations, and took minimal consideration of student performance or course content to be at the emerging level. Reflections in which adaptations were more specific and based on student performance or course content were scored as developing. Reflections that were considered advanced included analysis of instructional techniques or strategies based on student performance and professional knowledge. 


\section{Emerging}

Across levels of teacher preparation, students reflecting on instructional decision making classified at the emerging level tended toward a teacher-centered position, and minimally considered student outcomes, goals, or perspectives. Adaptations centered on procedural changes and lacked evidence of using assessment data or professional knowledge to support instructional decisions. At the Foundations level, written reflections tended toward listing what the preservice teacher did without providing rationale for instructional decisions. Reflections at the Methods level described what happened during the lesson, including ways in which instruction might be modified, but did not include rationales for these changes. Likewise, reflections categorized as emerging at the Capstone level presented lists of tasks without evidence of reflective thinking. Table 2 provides illustrative excerpts from each level of preparation that scored as emerging in regards to instructional decision making.

Table 2. Emerging reflection on instructional decision making

\begin{tabular}{|l|l|}
\hline $\begin{array}{l}\text { Foundations (79\% of } \\
\text { all reflections scored } \\
\text { at the emerging level } \\
\text { of reflection) }\end{array}$ & $\begin{array}{l}\text { "I encourage her to be successful by modeling the way the task should be done. I } \\
\text { showed her how I would do the picture sort. I also competed against her for our } \\
\text { Boggle game. She has picked up some new methods by me showing her how to form } \\
\text { longer words. I also created a word search for her using the words she misspelled on } \\
\text { the QSI. I then tasked her to create her own word search for myself and a friend using } \\
\text { words she was comfortable with." }\end{array}$ \\
\hline $\begin{array}{l}\text { Methods (14\% of all } \\
\text { reflections scored at } \\
\text { the emerging level of } \\
\text { reflection) }\end{array}$ & $\begin{array}{l}\text { "While I used many of the routines and classroom management strategies that } \\
\text { students are accustomed to, many students responded to conversations and } \\
\text { attention-getters as expected. One thing I wished I had planned more for is how to } \\
\text { engage students who are not paying attention or discussing the questions asked with } \\
\text { their partners. While walking around the circle during the 'active listening' segment } \\
\text { throughout the story, some students were not listening and my time with them was } \\
\text { simply spent explaining what they should be discussing instead of hearing their } \\
\text { responses." }\end{array}$ \\
\hline $\begin{array}{l}\text { Capstone (7\% of all } \\
\text { reflections scored at } \\
\text { the emerging level of } \\
\text { reflection) }\end{array}$ & $\begin{array}{l}\text { "In my first lesson on fact and opinion, I asked students to tell me what they already } \\
\text { knew about facts and opinions. Then, as a group, we went through a PowerPoint } \\
\text { presentation that gave more information on the concepts. Following the new } \\
\text { information, we took a quiz, as a class, to determine whether given statements were } \\
\text { facts or opinions. For the next lesson, students worked independently to write facts } \\
\text { and opinions based on a given topic. This built upon the last lesson because they } \\
\text { were writing their own statements, rather than determining whether given } \\
\text { statements were facts or opinions." }\end{array}$ \\
\hline
\end{tabular}

\section{Developing}

Reflections on instructional decisions categorized as developing shared a common characteristic of descriptive rather than analytic reasoning, but did differ across levels of teacher preparation in significant ways (see Table 3). At the Foundations level, the preservice teachers provided global statements about adapting instruction, but did not reference student data or professional knowledge. 
Methods level reflections were still descriptive rather than analytical, yet contained evidence of consideration of the elementary students' misconceptions when adapting instruction. Capstone reflections contained evidence of consideration of the background and instructional needs of students, using global knowledge of students to plan instruction.

Table 3. Developing reflection on instructional decision making

\begin{tabular}{|l|l|}
\hline & EXCERPT \\
\hline $\begin{array}{l}\text { Foundations (55\% of all } \\
\text { reflections scored at the } \\
\text { developing level of } \\
\text { reflection.) }\end{array}$ & $\begin{array}{l}\text { The book was too small for her to write all of that so for the second page I asked } \\
\text { the writing was a challenge just because she had to write so much. With our verbal } \\
\text { help she finished it. After the lesson [partner teacher] and I talked and decided that } \\
\text { it would have been better if we made a larger book for her to write in and had } \\
\text { folded it prior to the lesson. It would also have been good if we had written the } \\
\text { repeated parts on each page and just left spaces for her to write the different } \\
\text { animals." }\end{array}$ \\
\hline $\begin{array}{l}\text { Methods (34\% of all } \\
\text { reflections scored at the } \\
\text { developing level of } \\
\text { reflection.) }\end{array}$ & $\begin{array}{l}\text { "After the lesson, I realized that I wish I had done the assessment differently. It was } \\
\text { a worksheet, but looking back it was too structured. I wish I would have left it more } \\
\text { open ended. Instead of having blanks, I wish I would have had everyone write the } \\
\text { beginning of the sentence together, and then given them the freedom to use } \\
\text { creativity and finish it however they wanted. I think that would have been more } \\
\text { meaningful for the students." }\end{array}$ \\
\hline $\begin{array}{l}\text { Capstone (11\% of all } \\
\text { reflections scored at the } \\
\text { developing level of } \\
\text { reflection.) }\end{array}$ & $\begin{array}{l}\text { "I will be able to understand how well students understood the assignment by } \\
\text { reviewing their final copy of the graphic organizer once completed. This } \\
\text { information will tell me what skills need to be review and discussed for next time. I } \\
\text { will look for student work samples that are good examples to help students for the } \\
\text { next time we have to complete the organizer." }\end{array}$ \\
\hline
\end{tabular}

\section{Advanced}

At the advanced level of reflection on instructional decisions, several patterns of significance were found across levels of teacher preparation (see Table 4). Instructional decisions were grounded in a wide variety of assessment data, used technical literacy instruction vocabulary and conceptual understandings to interpret instructional decisions, and expressed a sense of accomplishment and confidence that the instructional plan would succeed. At the Foundations level, the one reflection scoring in the advanced category referenced course material and developmental levels based on detailed assessment results. In Methods, reflections connected instructional decisions to professional knowledge and vocabulary, and were centered on individual student responses. In Capstone, reflections cited research-based instructional models, as well as used state standards to identify learning objectives. These reflections were also seen to anticipate students' misconceptions.

\section{Table 4. Advanced reflection on instructional decision making}

\begin{tabular}{|l|l|}
\hline & Excerpt \\
\hline $\begin{array}{l}\text { Foundations (14\% of } \\
\text { all reflections scored }\end{array}$ & $\begin{array}{l}\text { "This week with Cameron I incorporated some spelling activities based on the } \\
\text { assessment analysis I did on his spelling test. His instructional level is in the }\end{array}$ \\
\hline
\end{tabular}




\begin{tabular}{|l|l|}
\hline $\begin{array}{l}\text { at the developing } \\
\text { level of reflection.) }\end{array}$ & $\begin{array}{l}\text { derivational speller level, and I played a game with him where he had to eliminate and } \\
\text { group words with the same root." }\end{array}$ \\
\hline $\begin{array}{l}\text { Methods (43\% of all } \\
\text { reflections scored at } \\
\text { the developing level } \\
\text { of reflection.) }\end{array}$ & $\begin{array}{l}\text { "When looking at what the students wrote, there were some real strengths in taking } \\
\text { phrases from the book, such as 'your hands were warm and soft' and using specific } \\
\text { details such as Ada Ruth and her grandmother 'went hunting for food.' Then, many } \\
\text { students added strong pieces such as 'Will you come back because I'm crying for you?' } \\
\text { and 'I hope that you bring food.' These sentences really show that students were able } \\
\text { to think from the perspective of the character and understand how she was feeling } \\
\text { when her mother was away. In the future, I would like to continue having my students } \\
\text { write from different perspectives as it helped them connect to the literature and } \\
\text { understand the character on a deeper level." }\end{array}$ \\
\hline $\begin{array}{l}\text { Capstone (43\% of all } \\
\text { reflections scored at } \\
\text { the developing level } \\
\text { of reflection.) }\end{array}$ & $\begin{array}{l}\text { "Prior activities and student work samples revealed prior approximations and } \\
\text { misconceptions among the group regarding their views of the purposes of writing. } \\
\text { Writing samples have consistently offered a list of facts to describe an experience. } \\
\text { Their work showed little ability to expand upon ideas or to grasp the reader's } \\
\text { attention. In order to achieve proficiency of the concept of effective use of adjectives } \\
\text { in writing, this learning segment will offer scaffolded instruction within the gradual } \\
\text { release of responsibility model. All skills will be modeled by the teacher. Then } \\
\text { students will be given the opportunity to apply the learned skill through guided } \\
\text { practice. Finally, support will be withdrawn as the students will take the responsibility } \\
\text { to utilize the skills by identifying and producing adjectives and by utilizing them } \\
\text { within the context of writing." }\end{array}$ \\
\hline
\end{tabular}

Along with exploring the reflections across a matrix of levels of teacher preparation and categorizations of evidence of instructional decision making, we looked at percentages of reflections scoring at each level of development (See Table 5).

Table 5. Percentage of reflections per level of development

\begin{tabular}{|l|l|l|l|}
\hline & FOUNDATIONS & METHODS & CAPSTONE \\
\hline Emerging & $51 \%$ & $17 \%$ & $22 \%$ \\
\hline Developing & $47 \%$ & $54 \%$ & $44 \%$ \\
\hline Advanced & $2 \%$ & $139273 \%$ & $33 \%$ \\
\hline
\end{tabular}

Our intentional collection and analysis of the preservice teachers' reflections suggests that structures designed to support the development of reflective practice do impact their capacity for advanced reflection. We elaborate on this point in the discussion below.

\section{DISCUSSION}

Reviewing the different opportunities created within and across courses provided perspective and insight about our students' development as preservice teachers. We analyzed the content of our teaching structures (pedagogies) as well as the preservice teachers' reflections. We found pedagogies related to the modality, prompting, scaffolding, assignment structure and feedback on reflective 
practices supported the possibility for candidates to develop the adaptability, professional and personal dispositions, and independence necessary for entering the teaching profession.

\section{Modality}

In their review of literature on the development of reflection in preservice teachers, Risko et al. (2009) found that "multiple, multilayered opportunities" (p. 49) including individual and group settings, and a variety of learning processes and techniques appear to support reflection development and learning. At each stage of our program, preservice teachers had opportunities to reflect using multiple modalities. This deliberate practice made visible our belief that reflection need not always be formal, or written. By reflecting together with colleagues, reflecting verbally, and reflecting in short bursts, in addition to the more formal writing and video reflection, preservice teachers engaged in the types of reflection that are part of being an adaptive practitioner (Hammerness, Darling-Hammond, \& Bransford, 2005). They were also able to see that reflection itself is adaptable to the differences in schedules, expectations, and contexts that novice teachers will encounter as they are inducted into fulltime teaching positions.

\section{Prompting}

Analysis of reflections indicated the importance of the prompts given on the product of reflection. Across the three courses, the preservice teachers experienced acts of reflection that explored dispositions intertwined with preservice teachers' growing ability to "rethink key ideas, practices, and even values in order to change what they are doing" (Hammerness et al., 2005, p. 361). Through encountering this range of views, our students had the opportunity to recognize that reflection is not a singular thing or course assignment; it is an ongoing, recursive process and a habit of mind. With a working understanding of reflection that was not tied to a single type of prompt, the preservice teachers may feel more prepared to pose their own questions as they move into the classroom.

\section{Scaffolding}

As might be expected, we offered more direct modeling and support as we introduced practices of reflection in our Foundations class. In particular, preservice teachers engaged in guided practice to develop the listening skills and language that would make peer coaching more effective. As the preservice teachers progressed, they had more opportunities to practice adapting their professional knowledge to novel situations and the complexities of teaching. Aligned with Hammerness, DarlingHammond, Grossman, Rust, and Shulman (2005), in their description of key features of successful student teaching experiences, we found that this progression within our reflection opportunities provided a natural trajectory for entering the profession as colleagues who are supportive listeners who seek to learn from and with one another.

\section{Assignment-related expectations}

Loughran (2014) addressed the value of program coherence in helping future teachers develop effective pedagogical practices in complex environments. Likewise, we found great value in aligning assignments at different levels of professional preparation coursework. Consistency in terminology and expectations across the different courses afforded the preservice teachers the opportunity to focus on the introspective and abstract thinking we were asking them to do. We found, as did Risko et al. (2009), that 
clear definitions across progressively more independent assignments eased students' apprehension in approaching challenging tasks such as reflecting on videos of their own teaching.

Despite the success of these practices, we recognize the challenge of distilling a reflective mindset into a set of procedures that can be easily taught or evaluated. We recognized the inevitable limits of constructing the practice of reflection within the context of course assignments. We acknowledged tensions we experienced when grading the products of something that we hope to instill as a habit of mind.

\section{Feedback}

Though grades became less consequential to the work of reflecting as the preservice teachers progressed from course to course, feedback remained critical. The type and amount of instructor feedback on assignments varied from course to course, but opportunities for more immediate and authentic feedback from peers increased as the students progressed through the courses. Hammerness et al. (2005) report that, "the developmental process of learning to enact new skills can be supported by skilled coaching in peer support groups that allow teachers to explore, develop, strengthen, and refine teaching skills together" (p. 380). Likewise, we found that peers, who are often sharing similar experiences, may be in a better position to validate some emotional responses and share what they learned from a perspective that may feel more relevant. As preservice teachers assumed more responsibility as professional colleagues, they offered more targeted advice and questioned one another to consider alternative viewpoints. This also provided an authentic opportunity to cultivate confidence as they were able to share recommendations based on their successful trials. Growth in professional knowledge combined with experience listening and providing constructive feedback further prepared the preservice teachers not only to be better teachers, but to be stronger colleagues as they join school faculties.

\section{Limitations}

The results of this study should be considered with respect to a few limitations. First, the rubric we used to assess reflection only considered reflection on instruction, and did not consider any other aspects of professional learning or practice. Second, students engaged in reflection at varying intervals before or after a learning event occurred, and this may have implications for the level of reflection assessed. Finally, the instructional scaffolds and prompts we provided were useful in directing student reflections, but may have constrained their thinking.

\section{IMPLICATIONS AND CONCLUSIONS}

Through our work together, we arrived at a variety of conclusions for our own teaching practices. This suggested to us that there may not be a singular "best" way to prepare reflective practitioners, but that acknowledging the multiple facets of personal and professional development transpiring throughout preservice programs means that implications of this research are more contextual than universal and distinctive for different stakeholders.

In programs like ours that have the luxury of aligning multiple stages of coursework, it is worth exploring a variety of focuses for reflection. Reflecting on instruction as well as the dispositional and emotional elements that come to construct professional identity all have a valuable place in preparation 
programs (Hammerness et al., 2005). As individuals, as well as a teacher preparation program, we offer the following considerations developed from this study.

\section{Early program reflecting (Foundations)}

Although preservice teachers gain competence in reflective practices as they move through the teacher education program, students as early as the foundations level can exhibit characteristics of advanced reflection. In this same context, it is important to recognize that students at this early stage are wrestling with a lot of new knowledge, experiences, and emotional responses. Providing some structure and prompting gives preservice teachers a sense of the scope of what reflection might entail. Modeling and scaffolding different types of reflection point toward the types of reflective thinking and talking expected in the profession. At the same time, providing less-structured opportunities to reflect independently and with peers allows students to struggle to make sense of material and experiences in a way that may be more personally meaningful.

\section{Mid-program reflecting (Methods)}

After emerging professionals have been introduced to the structures and formats for reflecting in university courses, they may take the opportunity to reflect more deeply. At this stage they are engaged more deeply in field work providing more experiences in which to ground their reflective thinking as well as exposure to more perspectives such as the classroom mentor teacher, students, and university supervisor that may help them to explore their own perspectives. Reflecting on and evaluating multiple perspectives can support students in finding their own voices and identities as professionals.

\section{End-of-program reflecting (Capstone)}

As preservice teachers begin to exchange their roles as university students to assume those as classroom teachers, reflection can be used as a tool to synthesize learning across coursework and teaching experiences. Teacher educators' expectations may increase to incorporate more professional terminology and academic discourse. Supporting students at this level may include helping them to name their practices and make connections to the research and theory that guides them in order to put their most polished foot forward for external audiences such as reviewers of performance assessments.

Research has shown that teacher preparation programs can do more to structure instruction and support for preservice teachers as they grow in their ability to reflect on their instruction (Risko et al., 2009; Wade, Fauske, \& Thompson, 2008; Wake \& Bunn, 2016). In this article, we describe how teacher educators at one university investigated programmatic structures fostering the development of reflective professionals. Intentionally aligning our teaching of reflection allowed us to construct a valuable, working definition of reflection for ourselves and our students. Using a reflection rubric (Risko et al., 2009) as a guide, we discovered that preservice teachers' development as reflective professionals follows predictable patterns that can inform instructional approaches in professional programs. Finally, we found curricular mapping across courses for systematic introduction of opportunities for and expectations of reflection led to graduates who were able to reflect at advanced levels.

Kathryn L. Allen is an assistant professor in the Department of Literacy and Language at the University of Wisconsin Oshkosh (USA). Her research interests include teacher learning and the integration of technology in literacy education. 
Katherine Brodeur is an assistant professor in the School of Teaching and Learning at Bowling Green State University (USA). Her research interests include teacher learning and adolescents who experience difficulty with school literacies.

Madeleine Heins Israelson is an assistant professor at the College of Saint Benedict/St. John's University (USA). Her research interests include social justice and equity in teacher preparation and the integration of technology in literacy teaching and learning.

Keitha-Gail Martin-Kerr is a Lecturer in the Department of Curriculum and Instruction at the University of Minnesota (USA). Her research interest is in the area of literacy pedagogy in and out of school settings.

Lisa Ortmann is Assistant Professor of Literacy Education at The University of North Dakota (USA). Her research focuses on teacher preparation and development and $K-12$ disciplinary literacy instruction.

Debra S. Peterson is a Senior Education Specialist at Minnesota Center for Reading Research at the University of Minnesota (USA). Publications include articles in Reading Research Quarterly, Elementary School Journal, and the Reading Teacher. Awards include the International Literacy Association Albert I Harris award for reading research.

\section{REFERENCES}

Bransford, J., Darling-Hammond, L., \& LePage, P. (2005). Introduction. In L. Darling-Hammond \& J. Bransford (Eds.), Preparing Teachers for a Changing World: What Teachers Should Know and Be Able to Do (pp. 139). San Francisco, CA: Jossey-Bass.

Bransford, J., Derry, S., Berliner, D., Hammerness, K., \& Beckett, K. (2005). Theories of learning and their roles in teaching. In L. Darling-Hammond \& J. Bransford (Eds.), Preparing Teachers fora Changing World: What Teachers Should Know and Be Able to Do (pp. 40-87). San Francisco: Jossey-Bass.

Clarà, M. (2014). What is reflection? Looking for clarity in an ambiguous notion. Journal of Teacher Education, 66(3), 261-271.http://dx.doi.org/10.1177/0022487114552028

Dewey, J. (1933). How We Think. Boston: D. C. Heath.

Dewey, J. (1938). Experience and education, (6th ed.). New York: Macmillan.

Freese, A. R. (2006). Reframing one's teaching: discovering our teacher selves through reflection and inquiry. Teaching and Teacher Education, 22(1), 100-119.http://dx.doi.org/10.1016/j.tate.2005.07.003

Hammerness, K., Darling-Hammond, L., \& Bransford, J., (2005). How teachers learn and develop. In L. DarlingHammond \& J. Bransford (Eds.), Preparing Teachers fora Changing World: What Teachers Should Know and Be Able to Do (pp. 358-389). San Francisco: Jossey-Bass.

Hammerness, K., Darling-Hammond, L., Grossman, P., Rust, F., \& Shulman, L. (2005). The design of teacher education programs. In L. Darling-Hammond \& J. Bransford (Eds.), Preparing Teachers for a Changing World: What Teachers Should Know and Be Able to Do (pp. 390-440). San Francisco: Jossey-Bass.

Hattie, J., \& Timperley, H. (2007). The power of feedback. Review of Educational Research, 77(1), 81-112. https://doi.org/10.3102/003465430298487

Hayden, H. E., \& Chiu, M. M. (2013). Lessons learned: Supporting the development of reflective practice and adaptive expertise. In P. J. Dunston et al. (Eds.) 62nd Yearbook of the Literacy Research Association (pp. 279-296). Altamonte Springs: Literacy Research Association.

Hiebert, J., Carpenter, T. P., Fennema, E., Fuson, K., Human, P., Murray, H., Olivier, A., \& Wearne, D. (1996). Problem solving as a basis for reform in curriculum and instruction: The case of mathematics. Educational Researcher, 25(4), 12-21. Retrieved from https://www.jstor.org/stable/1176776

Jarvis-Selinger, S., Pratt, D., \& Regehr, G. (2012). Competency is not enough: Integrating identity formation into the medical education discourse. Academic Medicine, 87(9), 1185-1190. http://dx.doi.org/10.1097/ACM.0b013e3182604968

Loughran, J. (2002). Effective reflective practice: In search of meaning in learning about teaching. Journal of Teacher Education, 53(1), 33-43.http://dx.doi.org/10.1177/0022487102053001004

Loughran, J. (2014). Professionally developing as a teacher educator. Journal of Teacher Education, 65(4), 271283. http://dx.doi.org/10.1177/0022487114533386 
Miles, M. B., \& Huberman, A. M. (1994). Qualitative data analysis (2nd ed.). Thousand Oaks: Sage.

Nelson, F. L. \& Sadler, T. (2013). A third space for reflection by teacher educators: A heuristic for understanding orientations to and components of reflection. Reflective Practice, 14(1), 43-57. http://dx.doi.org/10.1080/14623943.2012.732946

Panos, A. (2015). Reflections from preservice to novice teaching: One perspective on the role of ePortfolios. Theory into Practice, 54(4), 292-300. http://dx.doi.org/10.1080/00405841.2015.1076692

Parkinson, P. T. (2008). Field-based preservice teacher research: Facilitating reflective professional practice. Teaching and Teacher Education, 25, 798-804. http://dx.doi.org/10.1016/j.tate.2008.11.017

Risko, V. J., Vukelich, C., \& Roskos, K. (2009). Detailing reflection instruction: The efficacy of a guided instructional procedure on prospective teachers' pedagogical reasoning. Action in Teacher Education, 31(2), 47-60. http://dx.doi.org/10.1080/01626620.2009.10463517

Russell, T., \& Martin, A. K. (2007). Learning to teach science. In S. K. Abell \& N. C. Lederman (Eds.), Handbook of Research on Science Education (pp. 1151-1178). Mahwah: Lawrence Earl baum.

Schön, D. A. (1983). The Reflective Practitioner: How Professionals Think in Action. New York: Basic Books.

Schön, D. A. (1987). Educating the Reflective Practitioner: Toward a New Design for Teaching and Learning in the Professions. San Francisco: Jossey-Bass.

Shulman, L. S. (1987). Knowledge and teaching: Foundations of the new reform. Harvard Educational Review, 57(1), 1-23. http://dx.doi.org/10.17763/haer.57.1.j463w79r56455411

Snow, C. E., Griffin, P., \& Burns, M. S. (Eds.), (2005). Knowledge to Support the Teaching of Reading: Preparing Teachers for a Changing World. San Francisco: Jossey-Bass.

Wade, S. E., Fauske, J. R., \& Thompson, A. (2008). Prospective teachers' problem solving in online peer-led dialogues. American Educational Research Journal, 45(2), 398-442. http://dx.doi.org/10.3102/0002831207308224

Wake, D., \& Bunn, G. (2016) Teacher candidate dispositions: Perspectives of professional expectations. Teacher Educator, 51(1), 33-54. http://dx.doi.org/10.1080/08878730.2015.1107440

\section{APPENDIX}

\section{Appendix A. Reflection rubric}

\begin{tabular}{|l|l|l|l|}
\hline $\begin{array}{l}\text { Identification of a } \\
\text { specific aspect of } \\
\text { the lesson }\end{array}$ & $\begin{array}{l}\text { EMERGING } \\
\begin{array}{l}\text { Reflection includes surface } \\
\text { or general descriptions of } \\
\text { the lesson; reporting or } \\
\text { retelling what occurred } \\
\text { without any analysis of } \\
\text { why students responded as } \\
\text { they did }\end{array}\end{array}$ & $\begin{array}{l}\text { DEVELOPING } \\
\text { sescription is more } \\
\text { specific and includes some } \\
\text { student responses and } \\
\text { performance are attributed } \\
\text { to factors external to } \\
\text { instruction }\end{array}$ & $\begin{array}{l}\text { ADVANCED } \\
\text { Description is specific } \\
\text { and multiple } \\
\text { explanations for the } \\
\text { outcomes are } \\
\text { considered; includes } \\
\text { factors specific to the } \\
\text { instructional decisions } \\
\text { and behaviors of the } \\
\text { teacher }\end{array}$ \\
\hline Perspectives & $\begin{array}{l}\text { Reflection is rooted in } \\
\text { personal experience only. }\end{array}$ & $\begin{array}{l}\text { Reflection connects to one } \\
\text { or two other sources or } \\
\text { perspectives (e.g. other } \\
\text { colleagues' experiences, } \\
\text { research, theory, students } \\
\text { backgrounds, experiences, } \\
\text { cultures) and considers } \\
\text { how these might impact } \\
\text { teaching and learning }\end{array}$ & $\begin{array}{l}\text { Reflection connects to } \\
\text { multiple sources or } \\
\text { perspectives and } \\
\text { considers how they } \\
\text { might impact teaching } \\
\text { and learning }\end{array}$ \\
\hline
\end{tabular}




\begin{tabular}{|l|l|l|l|}
\hline $\begin{array}{l}\text { Instructional } \\
\text { decisions }\end{array}$ & $\begin{array}{l}\text { Reflection lists global, } \\
\text { highly general adaptations } \\
\text { for instruction. }\end{array}$ & $\begin{array}{l}\text { Majority of the } \\
\text { adaptations are specific } \\
\text { instructional techniques or } \\
\text { strategies based on the } \\
\text { responses and } \\
\text { performance of students. }\end{array}$ & $\begin{array}{l}\text { All the adaptations are } \\
\text { specific instructional } \\
\text { techniques or strategies } \\
\text { and are based on } \\
\text { students' performance, } \\
\text { knowledge of research, } \\
\text { theory, and course } \\
\text { content. }\end{array}$ \\
\hline $\begin{array}{l}\text { Rationale for } \\
\text { instructional } \\
\text { decisions }\end{array}$ & $\begin{array}{l}\text { Reflection provides little or } \\
\text { no rationale for the } \\
\text { adaptations suggested }\end{array}$ & $\begin{array}{l}\text { The majority of the } \\
\text { adaptations are supported } \\
\text { with reasoned thinking } \\
\text { about instruction; } \\
\text { superficial connections are } \\
\text { made to sources of } \\
\text { evidence (e.g. student } \\
\text { work, assessment data, } \\
\text { research, theory). }\end{array}$ & $\begin{array}{l}\text { All the adaptations are } \\
\text { supported with evidence } \\
\text { including the analysis of } \\
\text { student work, } \\
\text { assessment data, } \\
\text { research, theory and/or } \\
\text { course content. }\end{array}$ \\
\hline Commitment to \\
action & $\begin{array}{l}\text { Reflection includes } \\
\text { statements of action } \\
\text { without specific steps for } \\
\text { implementation or } \\
\text { application. }\end{array}$ & $\begin{array}{l}\text { Reflection includes } \\
\text { statements of action with } \\
\text { general ideas of how the } \\
\text { adaptation could be } \\
\text { applied at some future } \\
\text { date. }\end{array}$ & $\begin{array}{l}\text { Statements of action } \\
\text { with specific steps for } \\
\text { immediate application } \\
\text { to instruction. }\end{array}$ \\
\hline
\end{tabular}

Modified from Risko, V. J., Vukelich, C., \& Roskos, K., 2009.

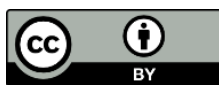

Copyright for the content of articles published in Teaching \& Learning Inquiry resides with the authors, and copyright for the publication layout resides with the journal. These copyright holders have agreed that this article should be available on open access under a Creative Commons Attribution License 4.0 International (https://creativecommons.org/licenses/by/4.0). The only constraint on reproduction and distribution, and the only role for copyright in this domain, should be to give authors control over the integrity of their work and the right to be properly acknowledged and cited, and to cite Teaching \& Learning Inquiry as the original place of publication. Readers are free to share these materials - as long as appropriate credit is given, a link to the license is provided, and any changes are indicated. 